\title{
What Has Become of the Japanese Model?
}

\author{
Luke Gower
}

$\mathrm{N}$

O nation projects images of a distinctive system of political economy in quite the way that Japan does. During the 1970 s and 1980 s, many observers became convinced that Japan's decades of consistently high economic growth were due to the unusual institutions of its capitalism. These idiosyncrasies were thought to constitute a 'Japanese model', from which policy-makers in other countries could learn lessons in economic management.

A review of that idea is now in order. Japan's GDP grew by only 2.1 per cent between 1992 and 1995, compared with an average of 6.1 per cent in the other members of the Group of Seven. Unemployment at 3.4 per cent is near a record high, and the financial system is in disarray. 'These problems are likely to persist. For although growth in 1996 was firm, the plunge in GDP in the second quarter of 1997 was the largest in 23 years. Moreover, the damage that this has done to economic recovery has been seriously accentuated by a crisis in the financial system. The effects of persistently weak productivity improvements will soon be compounded by the retirement of a large cohort of workers. Labour inputs and aggregate savings ratios are therefore likely to dwindle, taking long-run growth down with them.

These vicissitudes of economic maturity and the measures that will be required to cope with them have disillusioned many erstwhile believers in the Japanese model. Japanese policy-makers in particular are now less confident in their interventionist approach, and show correspondingly greater interest in market-oriented reform. This article explains how the change in thinking has come about.

\section{Defining the Japanese Model}

Two broad perspectives have dominated debate about Japan's high growth rate in the post-war era: the growth-accounting approach and the Japanese model. Proponents of the former perspective, which has been elevated to prominence in an East Asian context by Paul Krugman (1994), decompose economic growth into flows of resources into productive sectors of the economy and the improvement of technology. Although growth-accounting theorists disagree about the relative importance of these two factors, most would agree that they jointly explain Japan's economic growth in the 20th century. Most would also agree that, because Japan has almost exhausted the potential for any further exceptional expansion from a rapidly in- 
creasing resource base or from reallocating existing resources, the difference between Japanese growth rates and those in the rest of the developed world is likely to diminish. Some would add that the contraction of this growth differential is all the more certain given that Japan is approaching technological parity with the countries that it once strove to emulate (Saxonhouse, 1994). In short, growth-accounting theorists think that tightening resource and technology constraints will overshadow whatever positive influence domestic economic institutions may have on Japan's potential growth rate.

Proponents of the Japanese model find this reasoning too pessimistic and mechanical. They argue that Japan is a special case, with indigenous political and economic institutions that contribute to economic growth in ways not recognised by growth accounting (Johnson, 1982). In particular, they infer a causal link between the rapid rates of Japanese economic growth after World War II (see Figure 1) and the distinctive institutions of Japanese capitalism which were emerging at the same time. Since many of those institutions are now fixtures of the Japanese economy, proponents of the model often doubt that Japanese per capita growth must necessarily decline over the long run.

\section{Figure 1: Real per capita income percentage growth rates in Japan and the United States, 1901-94}

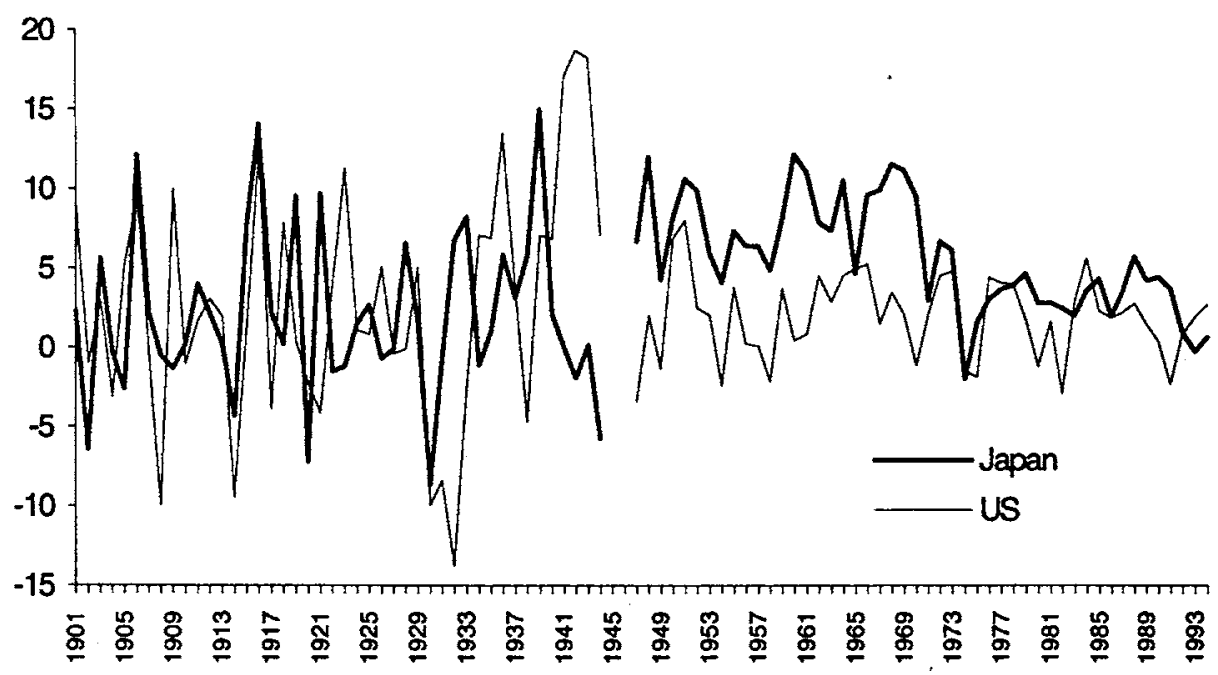

Note: The observations for 1945 and 1946 were outliers and have been suppressed. Source: Maddison (1995). 
Among proponents of the model there has been only a limited consensus on the question of which institutions have been most responsible for economic growth. Many mainstream economists have drawn attention to the more unusual properties of Japanese corporate governance and industrial organisation, which they think are well suited to mobilising resources. 1 But another influential group has contested that emphasis, arguing that the Japanese state has used industrial policy with extraordinary dexterity, and that it has successfully identified and supported those industries which were essential to growth. ${ }^{2}$ Although the Ministry of International Trade and Industry (MITI) is the most conspicuous agent of these policies, other government agencies, such as the Bank of Japan and the Ministry of Finance, have also played key roles in the planning of economic activity.

For at least two reasons, it is those versions of the Japanese model which emphasise the importance of state planning and regulation that warrant the closest scrutiny. First, they are better known and more influential than most of the industrial organisation theories. The state's planning role in post-war Japan is widely appreciated and admired, particularly among policy-makers from other (commonly East Asian) countries who seek to replicate Japanese economic history. Second, the state's ability to deliver economic growth by means of economic planning and regulation has become increasingly contentious. The government's failure to stimulate recovery in the course of the current slowdown seriously undermines many of the claims of its supporters, and the threat of slower growth over the long term raises strong arguments against a regulated and managed economic system.

\section{The Recent Slowdown}

The Japanese model suffered its first serious setback in the early 1990s, when the rate of economic growth suddenly fell. International competitiveness dropped as the real exchange rate appreciated; the financial system was destabilised by the collapse of asset prices; and conditions in the labour market deteriorated sharply.

Although the causes of the downturn are still debated, monetary factors and speculative behaviour feature prominently in most explanations. During the late 1980s, stable consumer prices and an appreciating exchange rate produced an accommodating monetary policy. In contrast to stable consumer price inflation, and in response to the loose monetary policy, asset prices rose substantially. Between January 1987 and December 1989, stock prices on the First Section of the Tokyo Stock Exchange doubled. Over a similar period, the price of urban land in the six major cities did the same. The eventual correction in asset prices was a substantial one: stock prices fell to 40 per cent of their peak level and, after several years of slow recovery, they have not risen far above that point. At the same time, urban land values have collapsed by 22 per cent since 1990 and they are yet to reach their nadir.

\footnotetext{
${ }^{1}$ See Aoki (1990) for a survey.

2 Johnson (1982) is the classic contribution.
} 
The problems of unstable asset prices were exacerbated by financial institutions, which mistook the temporary hike in asset values for a real and permanent shock. On the assumption that asset prices would remain high, financial institutions extended credit on a massive scale to borrowers who offered land as collateral. When the correction in land prices occurred and borrowers defaulted, lenders were left with low-value collateral and bad loans which, even now, are conservatively estimated to be of the order of $¥ 27$ trillion (A\$314 billion).

The recent crisis in financial markets underscores the severity of these problematic bad loans and it is an embarrassment to admirers of the Japanese model. Previous financial crises - most notably that of 1965 - were dealt with decisively by government and business. The inability of those same parties to deliver similar outcomes in the 1990 s is a poor reflection on contemporary Japanese economic management.

The financial crisis has had severe consequences for the personal and nonfinancial corporate sectors. And its recent deepening does not augur well for the future. Those who had borrowed against the value of land have been driven into bankruptcy in large numbers (Figure 2), and banks have become much more cautious in their lending policies, particularly where individuals and small businesses are concerned (APEG, 1997:50). This is highly problematic for a country like Japan, which relies heavily on small business for its output and employment.

Figure 2: Liabilities generated by business failures, 1990q1 - 1997q1 (Fbn)

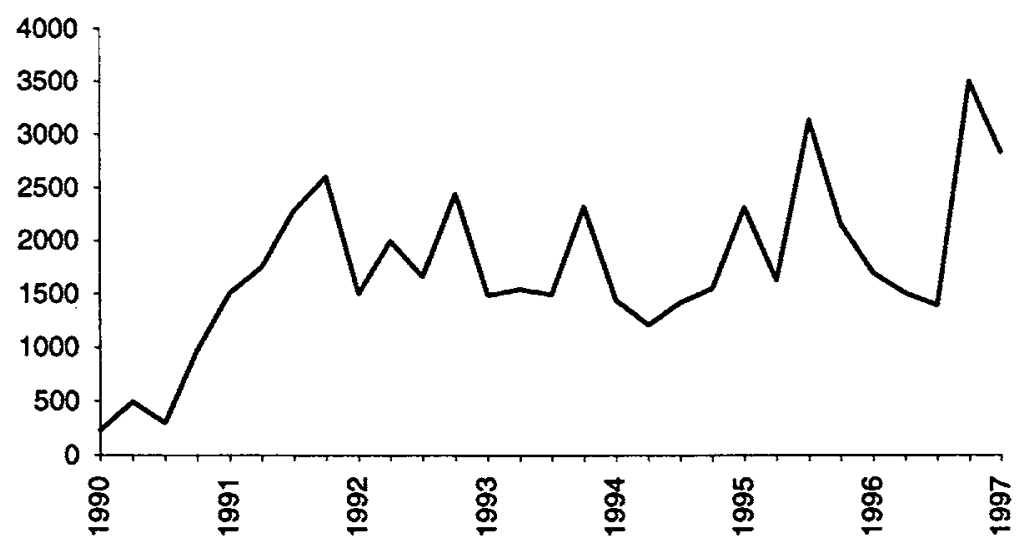

Sources: Tokyo Shookoo Research Ltd; Nikkei Telecom.

A further problem has been the acute drop in international competitiveness. Between 1990 and 1995, the yen appreciated by 25 per cent in real terms. Initially, falling wealth led to a decline in imports, and the current-account surplus expanded (in yen terms) by 42 per cent between 1991 and 1994. The nominal value of the 
currency was marked up accordingly. Some modest deflation subsequently offset the reduction in competitiveness that the nominal appreciation had induced. However, the transmission of nominal exchange rate impulses to domestic prices in Japan is notoriously unreliable (Marston, 1990), and deflation in the tradable goods sector was not sufficient to restore competitiveness. It has only been in the last few quarters that depreciation of the currency has allowed exports to contribute substantially to growth.

Table 1: Real and nominal exchange rates, 1990-96

\begin{tabular}{ccc}
\hline Year & Real exchange rate ${ }^{\mathrm{a}}$ & Nominal exchange rate $^{\mathrm{b}}$ \\
\hline 1990 & 100 & 144.8 \\
1991 & 95 & 134.7 \\
1992 & 92 & 126.7 \\
1993 & 81 & 111.2 \\
1994 & 77 & 102.2 \\
1995 & 75 & 94.1 \\
1996 & 89 & 107.7 \\
\hline
\end{tabular}

Notes: ${ }^{a}$ Figures are expressed in index form. ${ }^{b}$ Yen per US dollar.

Source: APEG (1997).

Figure 3: Growth rates in two post-war Japanese slowdowns

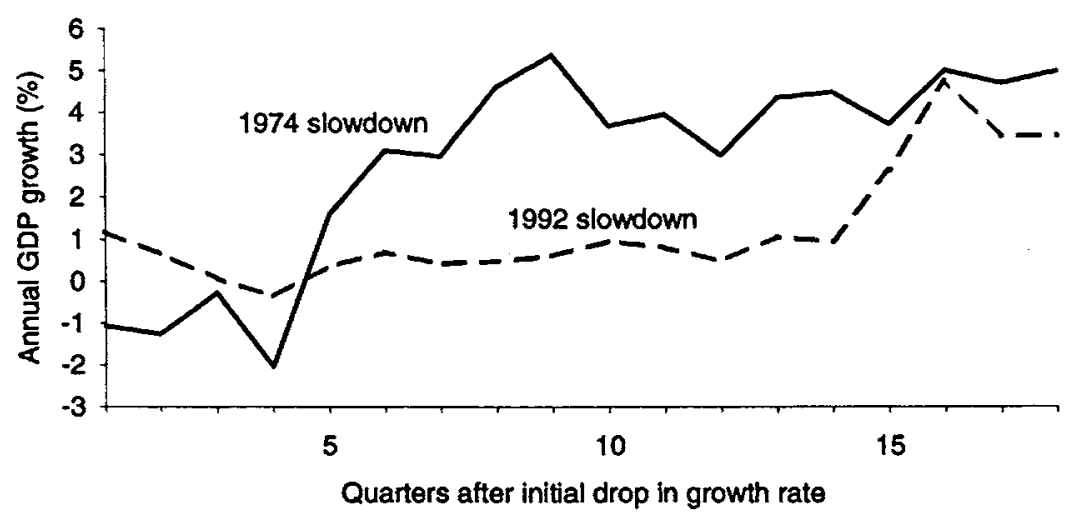

Notes: The graph plots the year-on-year real growth rate beginning with the point at which a quarter-on-quarter fall in the flow of GDP was first recorded. By this definition, the starting points for the two slowdowns are the first quarter of 1974 and the second quarter of 1992. The Economic Planning Agency uses a more complicated formula for gauging the business cycle; its estimates suggest that the most recent slowdown ran from February 1991 to October 1993. Many private commentators believe that the actual slowdown persisted beyond that endpoint.

Sources: Bank of Japan, Economic Statistics Annual, various issues; Nikkei Telecom.

As prospects for the corporate sector worsened, so did conditions in the labour market. At 3.4 per cent, the official unemployment rate may seem low, but it is underestimated since labour market practices in Japan mean that workers can be idle 
or virtually unemployed without appearing to be so in the official statistics. According to McCormack (1997), if US Bureau of Labor Standards criteria were used in Japan, the rate of unemployment would be closer to 8.9 per cent. A slack labour market is also suggested by the more closely watched ratio of job offers to seekers, which has a long-run average of 0.88 but is currently at 0.75 , and has recently been as low as 0.6 .

Perhaps the most perplexing aspect of this slowdown is its persistence. This is not only the deepest, but also the longest, slump in post-war Japanese history. The only post-war slowdown of comparable magnitude occurred around the time of the first oil shock in 1973. As Figure 3 shows, growth rebounded much more quickly on that occasion. For that reason, and the fact that the Japanese business cycle is not synchronous with sustained growth in the rest of the industrialised world, many Japanese commentators are beginning to doubt the flexibility of their economy and the virtues of the model on which it is supposedly founded.

\section{Implications for the Model and the Prospects for Reform}

In raising concerns about the inflexibility of the economy, the 1990 s slowdown draws attention to the longer-term limits to Japanese growth. Japan's trend rate of growth has actually been easing for some time, and for reasons that are quite independent of the 1990s malaise. The data summarised in Figure 1 reveal that, after averaging 8.4 per cent between 1950 and 1970, average annual income growth per head slumped to 4 per cent in the $1970 \mathrm{~s}$, and then 3.4 per cent in the $1980 \mathrm{~s}$. Most proponents of the Japanese model missed this shift of gear. It was not until the 1970s that the epithet 'Japan Inc.' gained currency; it was not until 1979 that Ezra Vogel (1979) foretold the arrival of 'Japan as Number One'; and, as Saxonhouse (1994) notes, it was not until the mid-1970s that a clutch of prominent forecasters with faith in the model forecast 10 per cent annual Japanese growth rates for the better part of 20 years. ${ }^{3}$

By the time these prophecies had been made, the Japanese economy had indeed become large. But, as growth-accounting theory predicted, by the 1970 s and 1980s it was approaching its limits. The manufacturing sector had long been acquiring under-utilised resources from agriculture. It had also been generating productivity growth by absorbing new technology from abroad and it had been rebuilding the nation's war-damaged industrial base with the most modern forms of capital. By the 1980 s, the potential for any further such gains had been largely spent. As a result, Japan's ability to achieve exceptional growth rates was considerably diminished.

Now Japan faces an additional set of constraints. Foremost among them is the country's demographic profile. Japan is one of the most rapidly ageing industrialised economies: its working-age population will decline by a net $4.6 \mathrm{~m}$ workers in the first two decades of the 21 st century. By 2015 one-quarter of the population will be

3 The Economist deserves credit for having noticed Japanese growth as early as 1963, when it published its series of essays on the subject. 
aged over 65, and by 2049 that proportion will have risen to one-third (see Figure 4).

The most obvious problem associated with an aging population is a tightening labour supply constraint. To deal with this problem, the Japanese parliament is currently debating reforms to the tax system which will improve the access of women to the workforce, and it has already strengthened the provisions of longstanding, but previously unenforced, equal employment opportunity legislation governing overtime. In order to encourage greater workforce participation among the elderly, social security reform is also being debated.

Figure 4: Age composition of Japan, 1995 and 2005

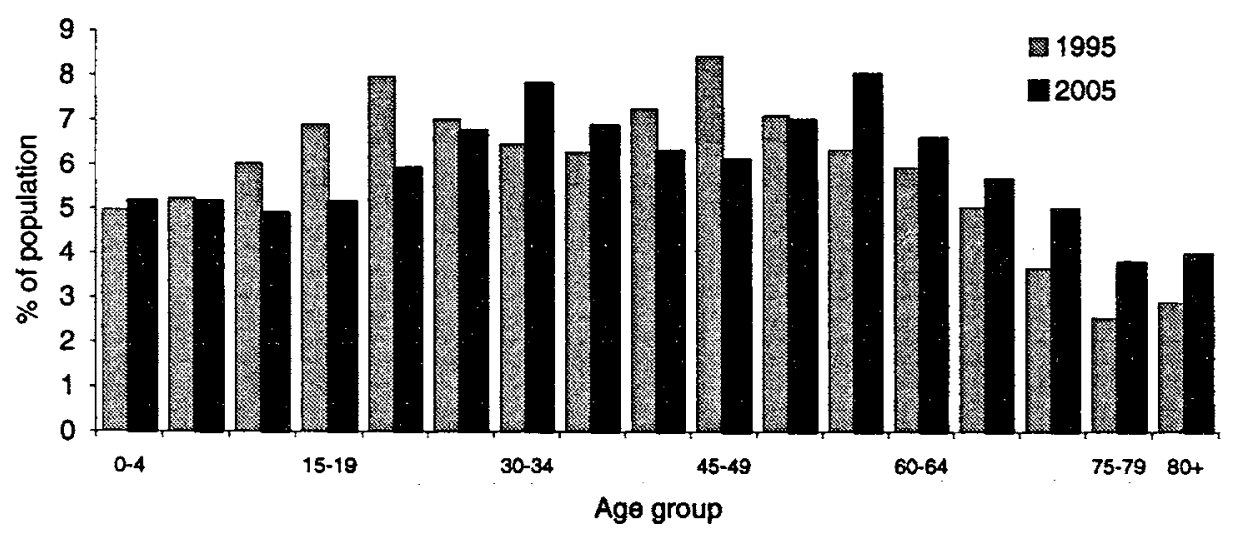

Source: APEG (1997).

Besides facing a diminishing labour supply, Japan is likely to experience lower savings rates as a result of its aging population. Aging implies a rising dependency ratio, which will inflate expenditure on social security for the elderly and ultimately increase the tax burden. Furthermore, since the elderly often have a high average propensity to consume, the rising proportion of them in the population will put downward pressure on aggregate savings rates. To the extent that international capital mobility is imperfect, both of these considerations imply that Japan will have a smaller pool of savings on which to draw for future investment. ${ }^{4}$

If history offers any guidance, the productivity slowdown of recent years and the diminishing pool of savings are likely to matter more than the tightening of the la-

\footnotetext{
${ }^{4}$ An alternative hypothesis, advanced by Hayashi (1986), is that the Japanese savings rate has been high because the Japanese bequeath wealth to their children. As economic growth slows, this incentive should weaken and the rate of saving should fall.
} 
bour supply constraint. ${ }^{5}$ Growth accounting studies usually indicate that Japan's growth has been driven more by productivity and capital accumulation than by rising labour inputs (Kim \& Lau, 1994; Drysdale \& Huang, 1997; Denison \& Chung, 1976).

Liberal financial markets are increasingly being seen as a way of managing the problem. Although financial deregulation has been in progress for about 17 years, ${ }^{6}$ it was radically accelerated in November 1996 when Prime Minister Hashimoto announced a major overhaul of the financial system. This program was simultaneously a response to the belief that the existing regulated financial structure was performing badly and an explicit response to the long-run problems presented by aging (Economic Council, 1996). The program foreshadows further deregulation of the securities industry, changes to the Bank of Japan Law, more deregulation of the system under which foreign-exchange earnings are currently repatriated, and extensive reforms of the life insurance and funds management industries.

These initiatives go against the grain of the Japanese model, every variant of which endorses financial repression. The basic argument is that the Japanese state successfully set a ceiling on interest rates on private savings accounts over much of the post-war period, in order to minimise the cost of capital to industry and so promote growth (Zysman, 1983:248). The policy was effective partly because savings were supplied inelastically and partly because favourable tax treatment of them ensured reasonable effective rates of return (Hamada \& Horiuchi, 1987). If this was ever a good policy framework, it is certainly not appropriate now. The retirement of the current cohort of workers will have to be funded in some way. If social security and taxes are not to be the solution, then it is essential that the returns on private savings (including pension contributions) be maximised. That is why more efficient and competitive financial markets are currently being promoted.

The transition to a less regulated financial system is certain to deprive the state of some very important tools in economic planning. Already, financial deregulation has deprived the monetary authorities of their capacity to promote favoured industries through the application of 'window guidance'. This form of suasion was once an important means by which the authorities encouraged banks to lend to certain government-targeted industries, and it was exercised when large private banks borrowed from the Bank of Japan's discount window (a course of action to which they were regularly compelled when the financial system was tightly controlled). The practice has now fallen into disuse simply because, in liberal capital markets, banks no longer depend on the discount facility, and the leverage of the monetary authorities over the banks in relation to the direction of bank lending has lessened.

There is also the possibility that the state will eventually forfeit much of its control over the direction of capital as a result of the unravelling of the extensive system

\footnotetext{
${ }^{5}$ History may not be our most reliable guide. International capital mobility is now much higher than it was in the earlier post-war years, and domestic savings ratios may therefore prove less essential to Japanese capital accumulation in the future.

${ }^{6}$ Takeda and Turner (1992) provide an excellent summary of the process in its earlier phases.
} 
of state financial institutions. To date, regulation of the financial system has been configured to garner for the state a high proportion of personal savings: approximately 20 per cent of household savings are held through the state-run postal savings system - making it the largest system of socialised savings in the world. These funds are channelled to industries and activities which the state favours through a large network of state-operated financial institutions. Recently, the uses to which these funds are being put have been fiercely criticised from within the financial community and even from within the bureaucracy. The Minister for Health and Welfare has called for the privatisation of the postal savings system, publicly complaining that the Ministry of Finance does not earn enough on its investments. In large measure, the system performs poorly because the funds that it accumulates are channelled into industries in which Japan has a gross comparative disadvantage and which generate low rates of return (Calder, 1993:107).

This inability on the part of state-operated financial institutions to support highgrowth sectors epitomises the more general tendency of the state to pursue industrial policies that retard, rather than facilitate, structural adjustment. Although industrial policy has had many successes in Japan, there are many more cases of ministries having failed to discern which industries constitute the essence of Japan's comparative advantage. The failure of key sections of the bureaucracy to support the automotive and consumer electronics industries in the early post-war period are cases in point. At the same time, industrial policy has vigorously supported industries which have very limited growth potential; the most notorious examples are the provision of subsidised state finance to mining and agriculture.

Although recent governments have defended the role of state-run financial institutions in the face of mounting opposition, there is evidence that the tide of opinion is moving against conservative interests. Prime Minister Hashimoto has conceded that the public sector ought not to be exempt from the financial reform process (The Nikkei Weekly, 27 January 1997). More tellingly, policy circles have recognised that open capital markets could assume a greater role in influencing the course of industrial development. Reforms undertaken so far include the easing of eligibility requirements for listing on stock exchanges, the creation of new over-thecounter markets for furms with a strong research and development orientation, and deregulation of the eligibility requirements for the issuance of bonds. In addition, one of the purposes of the reform to Article 9 of the Anti-Monopoly Law is to provide large firms with incentives to form small subsidiary corporations that undertake research and development.

The government's change of attitude towards industrial policy is also reflected in its formal planning process. Government plans used to identify those sectors which were to be promoted with public resources and regulation. More recently, they have acknowledged the ability of markets to identify and promote promising industries. The most recent report of the Economic Planning Agencey (EPA) has earmarked few industries for support and it has stressed the importance of sweeping deregulation. Significantly, even where it did endorse the government's role in promoting certain industries, the plan identified deregulation of the operating envi- 
ronments of those industries as a priority. Most important, the announcement of a financial reform package in November 1996 has been followed with an announcement that the Hashimoto cabinet has adopted 2,823 individual deregulatory measures governing areas including energy, welfare, transport, telecommunications and real estate.

Private-sector lobby groups have endorsed deregulation. The peak Japanese employer body, Keidanren, has been actively demanding it and has insisted that the real appreciation of the yen needs to be met with measures that reduce factor prices. In many cases, this means deregulating factor markets. Significantly, Keidanren rarely calls for increased levels of protection. In fact, in late 1996 it presented the government with a list of 699 proposed deregulatory measures. Similarly, private bankers have backed demands for the dismantling of the national savings system. Apart from objecting to the fact that the system prices and allocates capital inefficiently, bankers complain that existing regulations give the government an unwarranted advantage in relation to deposit collection and so crowd them out of their principal factor market. This, they claim, is a particularly serious problem given that the banking system is experiencing extreme difficulties.

The arguments advanced by Keidanren and private bankers share a common motivation in Japan's recent economic misfortunes. Bankers argue that the current problems of the financial system need to be addressed now, and with a fundamental change of philosophy about the role of the state in the allocation of capital. Analogously, manufacturers, who face a high cost structure and a recessed domestic economy, present strong arguments that economic recovery hinges upon less state intervention in their affairs. Both sets of arguments dovetail with the longer-term pressures for economic reform. They show that while many deregulatory initiatives are motivated by the problems that Japan faces as it ages and reaches economic maturity, it is the current slowdown which furnishes reformers with a mandate for immediate deregulation.

\section{Conclusions}

The Japanese model has been strained by two simultaneous developments. The prolonged 1990s slowdown has shown that the economy is not immune from deepseated stagnation. More fundamentally, long-term constraints on growth are increasingly apparent, and market-oriented reforms are widely accepted as the appropriate response.

These developments discredit the Japanese model in two ways. First, events have simply overtaken the forecasts it produced. Japan has failed to meet the expectations that were held for it 20 years ago by advocates of the model. By contrast, the better growth-accounting studies, which eschewed Japanese exceptionalism, have aged extremely well. For instance, the landmark study by Denison and Chung (1976) predicted a post-2002 long-run growth rate of 3.2 per cent. This fits with the EPA's recent forecast of a 3.0 per cent average annual growth between 1997 and 2000. It is certainly nearer the mark than the optimistic projections that were issued in the mid-1970s by proponents of the Japanese model. 
The second sense in which the Japanese model has been discredited goes more to the heart of its assumptions. It is damaging enough that its forecasts of high and durable growth should have been invalidated so comprehensively. More serious are the failures of the institutions that were central to those forecasts. In forecasting 3 per cent annual real growth, the EPA (1997:34) warned that such a modest aspiration would be realised only if a program of appropriate deregulation and reform were implemented. Otherwise, growth would be no more than 1.8 per cent. That reform should be promoted by the very government bureaucrats who nurtured the formation of industrial policy is a telling indictment of theories which uphold the managerial capabilities of the state.

Yet despite history's rough handling of the Japanese model, and despite the current slowdown, the outlook for Japanese growth is not entirely grim. Many recent and planned reforms will undoubtedly produce a more efficient allocation of resources and relax constraints on the availability of capital and labour. Moreover, although Japan has surpassed the West in technology in many areas, in others it is still within the frontier, and so there remains unexploited potential for further productivity growth. For instance, Japan has been slow to join the latest revolutions in telecommunications and computing. However, over the next few years these industries are certain to contribute significantly to productivity.

Although the Japanese economy may eventually recover from its present malaise, economic growth will never again be exceptional in comparison with other industrial countries. And even if it should exceed the standards set by the industrialised world to some modest degree, the differential will not be attributable to an extraordinarily active public sector. It is time to put the exaggerated claims about the Japanese model back into historical perspective.

\section{References}

Aoki, M. (1990), 'Toward an Economic Model of the Japanese Firm' Journal of Economic Literature 28: 1-27.

Asia Pacific Economics Group (APEG) (1997), 'Japan', pp. 43-66 in Asia Pacific Profiles, vol. 2, Financial Times Newsletters and Management Reports, Hong Kong.

Bank of Japan, Economic Statistics Annual (various issues).

Calder, K. (1993), Strategic Capitalism, Princeton University Press, Princeton.

Denison, E. \& W. Chung (1976), 'Economic Growth and its Sources', pp. 53-162 in H. Patrick \& H. Rosovsky (eds), Asia's New Giant How the Japanese Economy Works, The Brookings Institution, Washington DC.

Drysdale, P. \& Y. Huang (1997), 'Technological Catch-Up and Economic Growth in East Asia and the Pacific', Economic Record 73(222): 201-11.

Economic Council (1996), Structural Reform in Six Areas, Economic Planning Agency, Tokyo.

Economic Planning Agency (EPA) (1997), The Japanese Economy: Recent Trends and Outlook, Coordination Bureau, Tokyo. 
The Economist (1963), Consider Japan, Gerald Duckworth \& Co., London.

Hamada, K. \& A. Horiuchi (1987), 'The Political Fconomy of the Financial Market', pp. 223-62 in K. Yamamura \& Y. Yasuba, The Political Economy of Japan, Vol. 1, Stanford University Press, Stanford.

Hayashi, F. (1986), 'Why is Japan's Savings Rate Apparently So High?', pp. 147-209 in NBER Macroeconomics Annual, MIT Press, Cambridge, Mass.

Johnson, C. (1982), MITI and the Japanese Miracle, Stanford University Press, Stanford.

Kim, J. \& L. Lau (1994), 'The Sources of Economic Growth of the East Asian Newly Industrialized Countries', Journal of the Japanese and Intemational Economies 8: 235-71.

Krugman, P. (1994), 'The Myth of Asia's Miracle', Foneign A/fairs 73(6): $62-78$.

Maddison, A. (1995), Monitoring the World Economy, Development Studies Centre, OECD, Paris.

Marston, R. (1990), 'Pricing to Market in Japanese Manufacturing', Journal of International Economics 29: $217-36$.

McCormack, G. (1997), 'Is Japan Facing Financial Armageddon?', New Asia Pacific Review 3(2): 10 15.

Nikkei Telecom, Japan News and Retrieval, Nihon Keizai Shimbun, Tokyo.

Saxonhouse, G. (1994), 'Japan: Growing Old Gracefully?', Intemational Economic Insights 5: 11-14.

Takeda, M. \& P. Turner (1992), 'The Liberalisation of Japan's Financial Markets: Some Major Themes', Bank of International Settlements, Basle (BIS Economic Papers No. 34).

Tokyo Shookoo Research Ltd, Bankruptcies Monthly (various issues).

Vogel, E. (1979), Japan as Number One: Lessons for America, Harvard University Press, Cambridge, Mass.

Zysman, J. (1983), Governments, Markets and Growth: Financial Systems and the Politics of Industrial Change, Cornell University Press, Ithaca.

I am grateful to Peter Drysdale, two anonymous referees and the editor for helpful comments on earlier drafts. The usual disclaimer applies. 